CORREIA, Jorge

- "Building as propaganda: a palimpsest of faith and power in Atlantic Maghreb around 1500".

In GHARIPOUR, Mohammad (ed.), Sacred Precincts: Non-Muslim Sites in Islamic Societies, Brill, 2014, 445-459.

ISBN: 978-900-427-906-3.

Citation index: Scopus 


\title{
Building as Propaganda A Palimpsest of Faith and Power in the Maghreb
}

\author{
Jorge Correia
}

Portugal held overseas possessions in Africa, South America and Asia from the beginning of the fifteenth century till very recently. This empire was the result of conquests of cities that belonged to other kingdoms, such as in the Maghreb or India, the establishment of commercial outposts in key points of the maritime routes along the Atlantic and Indian oceans coasts, or the creation of colonies in newfound lands, such as some Atlantic archipelagos or Brazil. The Moroccan project was a fundamental part of this overseas expansion. ${ }^{1}$ Amidst several motivations, the Crusader spirit was certainly one of the most important drives for the Portuguese to assault Northern Africa from the early 1400 s to 1500 .

The Portuguese presence in the region lasted from 1415, when King João I (1385-1433) started what would become a series of conquests, to 1769 . This last date represents the epilogue of a political, military, and commercial investment in the Maghreb, when the evacuation of the last stronghold was decided in Lisbon. For more than three and a half centuries, the Portuguese main expression of its territorial expansion consisted in isolated enclaves along the Strait of Gibraltar and Atlantic coasts, which corresponds today to a long seashore stretch in the Kingdom of Morocco, with exception of the Spanish city of Ceuta. This territory was never understood as a full colony by the Crown, with autonomous jurisdiction. It was rather based on the conquest and occupation of pre-existing Arab and Muslim cities, resulting in a network of isolated possessions directly ruled by the king through local captains and governors.

1 Luis Filipe Thomaz, De Ceuta a Timor (Lisboa: Difel, 1990).
The arrival of a new power, the Portuguese, carrying with them the Christian faith, also implied a reconfiguration of the urban fabric. As mentioned before, the most frequent military approach was the conquest which took over pre-existing established cities belonging to Maghreb political spheres such as Fez and Marrakesh. Occupied cities were, most of the time, too large for the Portuguese military resources to keep in permanent state of defense. In the cities the Portuguese occupied a pragmatic attitude was the rule, oriented towards sustainability in a hostile environment. Therefore, urban appropriations shrank cities, erased suburbs, and promoted the opening of new streets and squares, closer to a Portuguese identification of the built environment. Significant reductions in perimeter and surface were carried out, in a procedure known as atalho (downsizing). ${ }^{2}$ In some cases, opportunities to experiment with more elaborate systems have left an urban heritage that is still present today.

All political and military seizures had carried with them a complete separation between the Christian populations inside the walls and the Muslims, whether Arab or Berbers, outside the fortified boundary. Only a few exceptions were permitted by the new city tenants. ${ }^{3}$ From north to

2 Jorge Correia, Implantation de la ville portugaise en Afrique du Nord: de la prise de Ceuta jusqu'au milieu du XVIe siècle (Porto: Faup publicações, 2008).

3 The so-called 'peace moor' (mouros de pazes) status, assigned to a limited number of native allies, was one instance. The other was that of the Jewish community but, even so, its neighborhood-mellah-within the walls was only sometimes authorized and instead relocated next door, with military protection offered by the Portuguese.

(C) KONINKLIJKE BRILL NV, LEIDEN, 2015 | DOI 10.1163/9789004280229_026 
south, the most relevant case studies include Ceuta (1415-1640), Ksar Seghir (Alcácer Ceguer, 1458-1550), Tangier (Tânger, 1471-1662), Asilah (Arzila, 1471-1550), Azemmour (Azamor, 1513-41) and Safi (Safim, 1508-41). ${ }^{4}$

The establishment of new settlements over non-previously urbanized areas was another paradigm of expanding the Portuguese presence, if yet less successful (Figure 24.1). The foundation of Mazagão (today a neighborhood called Cité Portugaise in El Jadida), in 1541, represents its outmost case study. Recent research has shown how this town's urban layout can be universally considered as a sacred precinct, the climax of all the urban experience acquired in a region where city walls generally meant a frontier for faith and possession.

This chapter's interest lies in the effective imposition of European and Christian models over an Islamic matrix that the new Portuguese overlords carried out in cities now empty of their native population, and the effects observed in the urban space, religious and civic architecture. Methodologically speaking, the research uses cartographical resources, morphological evidence, and field work to foster a cross-disciplinary approach between architectural history, archaeology, and history. The first steps of the analysis are directed towards the interpretation of the Christian basilica profile, in dialogue with or opposition to Muslim religious space, and the adaptation of mosques to churches. Parallel analyses will stress how administrative buildings, now devoid of their original function, used military architecture symbology as a discourse of power and as political reinforcement of this Christian claim in the early modern period. The overall urban image of the conquered and new-settled cities will be explored for an interpretation of its religious message, wishing to address Mazagão

To further readings on this population, please address to: José Alberto Tavim, Os Judeus na Expansão Portuguesa em Marrocos durante o Século XVI (Braga: APPACDM, 1997).

4 Original Portuguese names and dates of Portuguese occupation are indicated between brackets. as an ultimate Christian creation by the Portuguese in North Africa.

\section{The Historical and Geographical Context}

Portugal's experience with the Muslim world had already been a daily struggle when this young kingdom began its territorial fight against the Almoravid (1040-1147) and Almohad (1124-1269) Berber dynasties in twelfth and thirteenth-century Southern Iberia. Since the formation and recognition of Portugal as an independent kingdom in $1143,{ }^{5}$ the main political aim of Afonso Henriques (1143-85), the first Portuguese king, and his successors, was a military war against the 'infidel.' Until 1249, when the Al-Gharb al-Ândaluz (nowadays the region of Algarve in southern Portugal) was definitively conquered by Afonso III (1248-79), ${ }^{6}$ conquest was followed by the expulsion of Arab forces from the western Iberian strip. During the fourteenth century, mutual sea raids and skirmishes between Portugal and North Africa were frequent. The dispute over the Canary Islands and Italian ventures along the Maghreb Atlantic coast, demonstrated a growing interest in Northern Africa by European powers. Frequent Portuguese incursions in search of rich fishing resources or opportunities for piracy confirm the increasing knowledge of topographical information available to merchants. Therefore, the first organized Portuguese military campaign against Ceuta in 1415 should be seen not only as the starting point of the Portuguese overseas enterprise but also as the pursuing of long military interactions with Islam previously in Iberia Peninsula.

In fact, rather than a strictly territorial conflict, military conquests of Southern Iberian and Northern Maghreb Muslim strongholds carried with them an objective program of regaining former Christian areas and re-establishing the

\footnotetext{
5 Joaquim Veríssimo Serrão, História de Portugal (Lisbon: Editorial Verbo, 2001), I, 89-9o.

6 Serrão, História de Portugal, I, 137-140.
} 


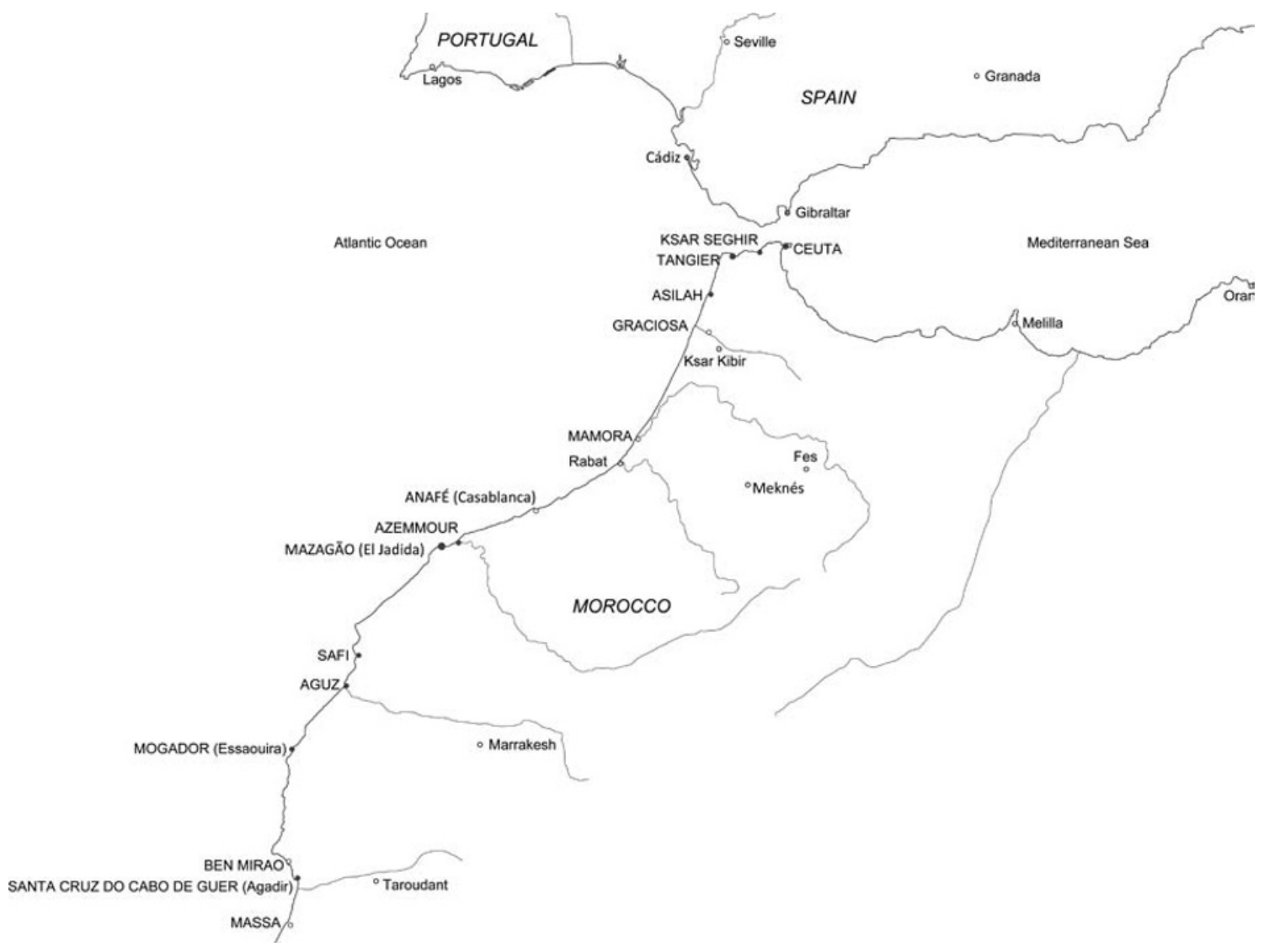

FIGURE 24.1 Southern Iberian Peninsula and Northwest Africa, indicating Portuguese possessions and some reference cities (C) JORGE CORREIA

cross over the crescent in their religious spaces. Moroccan territories, once part of the Roman province of Tingitana Mauritania, became officially Christianized by the fifth century $\mathrm{CE},{ }^{7}$ like all late-antique territories around the Mediterranean did upon the fall of the Western Roman Empire. That religious expression was maintained by a strong Byzantine influence in the period immediately following and was only replaced by Islam upon the Arab conquest in the late seventh century CE. Subsequent military episodes led to

7 Enrique Gozalves, "El culto indígena a los reys en Mauritania Tingitana. Surgimiento y pervivencia", in Memoria de Historia Antigua. Paganismo y cristianismo en el occidente del Imperio Romano (Oviedo: Universidad de Oviedo/Instituto de Historia Antigua, 1981) V, 16o-161. the Arab invasion of the Iberian Peninsula in 711 and the cantonment of Christian forces in the Asturias region from where the reconquista would begin. Separate Iberian kingdoms were formed in this reconquering context, including Portugal, and they fought from north to south in an attempt to expel the Muslim armies across the southern shore of the Strait of Gibraltar. While the Portuguese achieved that goal in 1249, only by 1492 did the joint crowns of Castile and Aragon take the city and Nasrid Emirate of Granada. Thus the project of continuing the slow, yet victorious, path further south was ever-present in a Mediterranean religious geography increasingly divided between north and south, west and east, where the powerful and also Muslim Ottomans were acquiring new domains and relevance. 
The conquest of Ceuta by the Kingdom of Portugal was the beginning of a settlement process that would comprise the takeover of several coastal urban assemblages and the establishment of castles at geostrategic points in the Maghreb. The whole process took more than a century, from 1415 until 1519, and rather than being pre-determined, it adjusted to the political instability of the region.

Traditionally, historiography has divided Portuguese military conquests and the establishment of commercial outposts in Northern Africa into two important areas. On the northern tip of the territory, the military seizure of Ceuta, followed by Ksar Seghir in 1458, Asilah and Tangier in 1471, defined what was then called the 'overseas Algarve' (Algarve de Além-mar). These former Muslim cities were integrated into the Portuguese Crown. However, their political influence only occasionally went beyond the limits of their walls. A peace treaty with the Kingdom of Fez allowed the European nation to extend their administration towards the hinterland for a period of a few decades at the end of the fifteenth century. 8

Further south, Portuguese ambition was to prevent Marrakesh from accessing its sea ports. The establishment of suzerainties in cities such as Azemmour (1486) or Safi (1488) in exchange for military protection clearly shows how vulnerable these places were, sometimes caught amidst internal Moroccan disputes. As a consequence, a few years later, both cities were militarily conquered (Safi, 1508; Azemmour, 1513) as a part of a broader plan by King Manuel I $\left(1495^{-15^{21}}\right)$ to ensure a stronger Portuguese presence in this southern area and a leading position in reaping the commercial benefits of its harbors. Massa (Meça) was another town that solicited Portuguese defense in $1497 .^{9}$ Several castles were built at strategically

8 Adolfo L. Guevara, Arcila durante la ocupación Portuguesa (1471-1549) (Tangier: Publicaciones del Instituto General Franco para la Investigación Hispano-Arabe, 1940), 28.

9 Letter from Manuel $\mathrm{I}$ to the inhabitants of Massa, Estremoz, January 11, 1497, in Arquivo Nacional da Torre do Tombo (AN/TT), Livro das Ilhas, fl. 50 (copy of the 16 th century). important sites along the coast, to provide additional protection for recently conquered cities, such as Mazagão, fifteen kilometers south of Azemmour, in 1514, or Souira Qedima (former Aguz), approximately twenty-five kilometers south of Safi, in 1519 .

Other castles were erected in Agadir (former Santa Cruz do Cabo de Guer) and Essaouira (then Mogador) in 1505 and 1506, respectively. The former was established by private initiative and bought by the crown in 1513 , in a clear message of Christian affirmation and military power in these southern lands. Nevertheless, Santa Cruz was also the ultimate turning point for Portuguese ambitions in the Maghreb when, in 1541, the fortress town was taken in a military assault that would result in a complete re-evaluation of the Portuguese presence in these territories. In 1515, both the failure to install a new fortress near present-day Mehdya (Mamora) and the missed opportunity to capture the city of Marrakesh had already shown fragilities in this war against Arab kingdoms, impeding Manuel I's broader objectives of conquering the whole Morocco country at that time. It is important to understand how this political and military interaction worked both ways. Intermittent periods of battle and peace played a fundamental role in the conditions of the daily life of the populations and their architectural or urban achievements. Muslim leaders of occupied cities, now vassals of the Portuguese Crown, were determined to resist and expel this foreign power. Information about possible attacks from the King of Fez or conflicts with the monarch of Marrakesh were frequent, and notably confirmed by Yahya $\mathrm{Ou}$ Ta'fouft, one of the most important 'peace moors' of the Portuguese. ${ }^{10}$ Others tried to take advantage of the bellicose situation and emerge as mediators between the Christian occupants and local tribes

10 For example: Letter by Nuno Mascarenhas to king Manuel I, Safi, April 3, 1517, in AN/TT, Cartas dos Governadores de África, n. 310) or Letter by Yahya $\mathrm{Ou}$ Ta'fouft to king Manuel I, Azemmour, Abril 27, 1517 (AN/TT, Corpo Cronológico, I, m.21, n. 93). 
that found themselves in the midst of a war that was not theirs. ${ }^{11}$

Within the Portuguese expansion campaign, North Africa was the closest territory, but this was not their only contact with the Muslim world. The rounding of the Cape of Good Hope in 1488, followed by navigator Vasco da Gama's arrival on the Malabar coast of India, exposed the Portuguese to the Islamic states around the Indian Ocean, namely those clustered near the Persian Gulf, the Arabian Peninsula, the Indian subcontinent and Southeast Asia. In the first quarter of the sixteenth century, the fortresses of Hormuz (today in Iran), Goa (in India), and Melaka (now a Malaysian town) created a maritime empire ${ }^{12}$ in which Portuguese ships claimed mercantile routes and collected taxes. But in these locations the social exclusivity of the conquered or founded cities was not as drastic as in Northern Africa, where the conquered urban space was completely devoid of native resident population. In fact, due to severe economic constraints and lack of human resources, architectural features of the Islamic layer were kept without any significant changes besides the natural overthrow of religious symbols. Thus, the Portuguese occupation enacted a superposition of the Christian layer over the Muslim one, its degree depending on the duration of their presence. From over two centuries in Ceuta $\left(1415^{-1640)}\right.$ to less than three decades in Azemmour (1513-41), the mid-sixteenth century witnessed a crisis that shrank Portuguese military expression in the Maghreb; Safi's occupation ended in 1541, and Ksar Seghir and Asilah in 1550. Although Ceuta and Tangier (until 1662), together with a new fortified investment in Mazagão, were the choices of the Crown as far as keeping enclaves in North Africa was concerned, building adaptation or urban appropriation occurred mainly during the immediate years following each

\footnotetext{
11 Letter by Yahya ben Belsba' to king Manuel I, end May, 1517 ?, in AN/TT, Gaveta 15, m.18, n. 5 .

12 Charles R. Boxer, O Império Marítimo Português, 14151825 (Lisbon: Edições 70, 2001), 62.
}

conquest, which meant the fifteenth and early sixteenth centuries.

\section{Building Adaptation}

The main sample for Portuguese intervention in the built environment of the Maghreb is provided by fabrics and structures appropriated after conquests in the fifteenth and early sixteenth centuries. New symbols of faith and power were imperative in Christian territories stripped from the kingdoms of Fez and Marrakesh. The key issue revolved around the foundation of a new image of the city where not only churches or cathedrals evolved from former mosques, but late-Gothic castles also effaced Muslim kasbahs or citadels. The presence of the Portuguese crown was to be apprehended through a rhetorical language that communicated a firm message to the permanently hostile outskirts. In fact, the ecclesiastical organization transplanted by the Portuguese to these territories did not wait for the actual military takeover for the establishment of dioceses. Frei Aymaro de Aurillac already held the title of Bishop of Morocco in 1413, as did Fr Nuno Álvares de Aguiar for Tangier's diocese in $1469,{ }^{13}$ in both cases two years prior to the conquest of each city. This fact clearly draws attention to the papal commitment to the Christian reconquest of the former Roman province of Tingitana Mauritania. Further south, and also years before Portuguese military settlements, in 1499, the district and diocese of Safi, comprising several places including Azemmour and Mazagão, was established by the Papal Bull In apostolice dignitatis. ${ }^{14}$

13 See: Atanásio Lopez, Obispos en la África Septentrional desde el Siglo XIII (Tangier: Instituto General Franco para la Investigación Hispano-Arabe, 1941), 183 and 168-69, respectively.

14 Bulla de Alexandre VI, 17 de Junho de 1499 (AN/TT, Bulas, maço 16, $\mathrm{n}^{\circ}$ 21), in Alguns Documentos do Archivo Nacional da Torre do Tombo, ácerca das navegações $e$ conquistas portugueza (Lisbon: Academia das Sciências de Lisboa / Imprensa Nacional, 1892), 95. 
Of all the historical facts upon the conquest of Ceuta in 1415, the investiture of three royal princes as knights by King João I is one of the most famous and most praised by chroniclers. ${ }^{15}$ This event occurred in the main mosque of the city, subsequently consecrated as a church. Spatial transformations were about to occur in order to adapt the existing religious constructions-Ceuta, Ksar Seghir, and Azemmour provide the most significant case studies. Not only do they configure different approaches and chronologies, but they also present the most relevant archaeological evidence.

Before plunging into the specific particularities of each case study, it is important to understand general prerogatives that offered typological and morphological advantages in the transition process from the Muslim to the Christian cult. Geography determines that mosques in northwestern Africa have their qibla wall, the direction toward Mecca, oriented towards the east or eastsoutheast. The niche that marked that wall-the mihrab - was then in the perfect position to be consecrated as the main altar of the new temple, respecting the Christian tradition of orienting churches' main chapels to the east. Another simple adaptation was the use of the minaret as a bell tower in the first years. These characteristics reveal that while these two religions were often antagonistic, for this geography they were more similar from a spatial perspective than the military context leads us to believe.

For many aspects of the Portuguese presence in the Maghreb, Ceuta was inevitably the paradigm to be followed. In the aftermath of the 1415 conquest, the building which offered the highest standards of dignity and nobility was the main mosque of the former medina (the Islamic city core), largely because of its imposing size. During the fifteenth century, it received the most impressive descriptions from visitors such as the Arab geographer $\mathrm{Al}$

15 Gomes Eanes de Zurara, Chronica de El-Rei D. João I (Lisbon: Escriptorio, 1899-1900), III, chapter 95.
Ansari ${ }^{16}$ and the priest Nicolau Lanckman de Valkenstein ${ }^{17}$ that provide a spatial understanding of the structure at the time of Portuguese occupation. Both texts acknowledge the existence of a large hypostyle room containing several naves. Although the actual number of these has been the object of discussion it is impossible to determine today. ${ }^{18} \mathrm{~A}$ tall central aisle between lower and lateral ones on each side was probably dominant, indicating an internal space which makes it closer to the basilican models so familiar and used in Christian temples during the Middle Ages in Europe right before and at the time of the conquest. Dedicated to Our Lady of Assumption, the new cathedral was clearly marked as 'Templũ Summũ' in Georg Braun's view of the city (Figure 24.2).

Considering this 1572 engraving a copy of an early sixteenth-century drawing, it reveals that the architectural features of the previous building were still discernible. ${ }^{19}$ And indeed, the central

16 There are three available translations of Mohammed Ibn Al-Qasim Ibn Mohammed Ibn Ahmad 'Abd Al-Malik Al Ansari's description of Ceuta, finished in 1422, seven years after the Portuguese conquest: $\mathrm{Al}$ Ansari, "Descrição de Ceuta muçulmana no século Xv," transl. Joaquim Figanier, Revista da Faculdade de Letras XIII (2ª série), 1 (1947), 10-52; Al Ansari, "Una descripción de Ceuta musulmana en el siglo $\mathrm{xv}$," transl. Joaquin Vallvé Bermejo, Al-Andalus 27 (1962), 398-442; Al Ansari, "La physionomie monumentale de Ceuta: un hommage nostalgique a la ville par un de ses fils, Muhammad B. Al-Qasim Al Ansari," transl. Abdel Magid Turki, Hespéris-Tamuda 20-21 (1982-83), 113-62. Nicolau Lanckman de Valkenstein was a priest and procurator of Friedrich III, who traveled in Queen Leonor's train to the city in 1451. António Brásio, "A primitiva catedral de Ceuta," in História e Missiologia. Inéditos e Esparsos (Luanda: Instituto de Investigação Científica de Angola, 1973), 66.

18 Gozalbes Cravioto suggests that 180 columns could be achieved, even more if one takes into account the columns that used to separate the former ablution courts. Carlos Gozalves Cravioto, El urbanismo religioso y cultural de Ceuta en la Edad Media (Ceuta: Instituto de Estudios Ceutíes, 1995), 93.

19 Jorge Correia, "Clash of Power and Creed: Cultural (Re)foundations in Northwest Africa," in Foundation, 


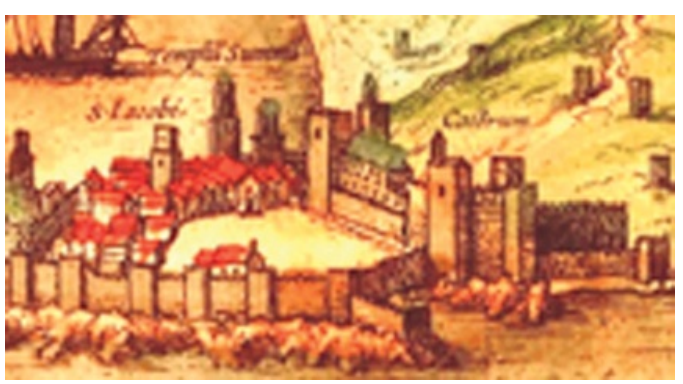

FIGURE 24.2 Detail from Septa

IN BRAUN ET AL., CIVITATES ORBIS TERRARUM, VOL. I, FOL. 56R

aisle appears to be confirmed by a row of scissorshaped roofs which seems to have a front portal. Reasonable doubts arise as far as the adoption of the former minaret is concerned because two towers can be observed in this view. The tallest, at the back of the building, suggests the preservation of the old Muslim minaret tower whereas its shorter version, to the right, looks like a bell tower, and is confirmed by later iconography. ${ }^{20}$

In addition to the basic characteristics that facilitated the Portuguese appropriation of the ancient main mosque of Ceuta, its high, wide central aisle suggests the ancient model of the Damascus mosque transported by the Umayyads during their westward advance in the eighth century and their taking over the Byzantine dioceses. While a raised, gabled transept was not an obligatory part of a mosque, it is particularly evident in Maghribi mosques. ${ }^{21}$ The same typology can be seen in the Qarawiyin mosque in Fez, the territorial reference city for Ceuta. Unlike in Damascus or Fez where the transept could be more easily recognized as a prominent part of the mosque, the difference in Ceuta was that the roofing system did not extend parallel to the qibla, but instead perpendicularly.

Dedication and Consecration in Early Modern Europe, Intersections vol. 22, eds. Maatern Delbeke and Minou Schraven (Leiden: Brill, 2012): 193 . Perspective of Ceuta around 1695 in João Thomas Correa, Livro de Várias Plantas deste Reino e de Castela (Lisbon: Livraria da Casa do Espírito Santo de Lisboa), fl. 58 .

21 Robert Hillenbrand, Islamic Architecture (Edinburgh: Edinburgh University Press, 1994), 50-53.
This specific feature made Portuguese adaptation a smoother process as the usual late-Gothic model for churches in Portugal could be straightforwardly transposed across the Strait of Gibraltar. Even though the Ceuta main mosque had several parallel naves, it was quickly reinterpreted from the preexisting Muslim structural basis. The morphologic result adopted the traditional medieval Christian mendicant profile translated by a religious building section formed by a higher central nave sided by two lower aisles, one on each side.

Gradually, the Portuguese appropriation of this space introduced changes, not only by eliminating eccentric aisles in the attempt to obtain a traditional plan of three naves, but also through the decorative language introduced on the main façade to declare the new faith housed within. Until the end of the seventeenth century, later than the period of Portuguese occupation of Ceuta, no further important architectural transformations were undertaken in the cathedral. ${ }^{22}$ Upon the Portuguese conquest in 1415, the symbolism was preserved and understood as the repositioning of the Christian faith after an era of Muslim interruption. The preservation of the holy site was maintained at all costs. Next to Ceuta, in the city of Tangier, one can more adequately speak of a succession of religious strata since the current day mosque is a seventeenth-century building that replaced the Portuguese cathedral, which had previously adapted the medieval Islamic mosque that was already built over a Byzantine church.

The same cannot be said of another religious building appropriated by the Portuguese in Azemmour. Here, in an urban environment that had its origins later in the Arab period, the need to establish a new presence was obvious. The main mosque was apparently of a smaller scale with no

22 Its state of ruin would determine the erection of a new cathedral by the Spaniards during the following century. Lorenzo Pérez del Campo, "Etapas en la construcción de la catedral de Ceuta" in Actas del Congreso Internacional "El Estrecho de Gibraltar," ed. E. Ripoll Perelló (Ceuta, 1987; Madrid: Universidad Nacional de Educación a distancia, 1988) 4, 42-43. 
evidence of a raised transept. No visual records remain from the Arab or subsequent Portuguese phases, except the engraving in Braun's Civitates Orbis Terrarum which depicts several prismatic minarets towers inside the walled perimeter. ${ }^{23}$ One is led to assume, given the current accentuated gap between the street level and the lower floor in the interior, that the present mosque is the same building that has evolved from the medieval period, adapted as a church during the short Christian occupation of the Portuguese in Azemmour, from 1513 to 1542 .

If so, the adaptation process was much more straightforward than in Ceuta. The former mosque, which presented three parallel aisles to the qibla, saw its mihrab immediately converted into an altar. In 1541, the new church was already described as having three naves ${ }^{24}$ which corresponds to the oldest part of the present-day mosque in the Kasbah/Mellah neighborhood, the former Portuguese area of the town. Even though it did not possess a raised transept in the direction of the mihrab, a virtual cross-space became the most important arched and visual perspective towards the east, with no need to disturb the general boxshaped exterior of the building.

The temptation to approximate pre-existing religious buildings to the religious mendicant three-ailed profile was probably greater than the means and resources to do so. Nevertheless, whenever an opportunity to build a church from scratch happened, that was the model to be followed: the ruins of the Portuguese cathedral at Safi still document the erection of a three-nave late-Gothic basilica. It was definitely an exportable religious typology for a growing empire during the fifteenth and early sixteenth centuries. Nevertheless, the transformation of Muslim structures was a much more frequently utilized process in such an

23 Georg Braun, Frans Hogenberg and Simon Novellanus, Civitates Orbis Terrarum (Cologne: Philippus Galleus, 1572), I, 56-56v.

24

Order by António Leite, Azemmour, April 12, 1541 in AN/TT, Corpo Cronológico, II, m. 234, n. 131. economically challenged expansion as that of the Portuguese.

This was the case of Ksar Seghir in 1458. The symbolic meaning derived from the substitution of faith rituals and objects was probably even more important than the financial constraints. Ksar Seghir was a small town on the southern shore of the Strait of Gibraltar, and it had played an important role as a crossing point to the Iberian Peninsula during the Middle Ages. The Portuguese intervention in the town's mosque was less discreet than Azemmour's adaptation to Christianity, dealing here with a more longitudinal space, just like in the neighboring city of Ceuta.

The mosque the European settler encountered in Ksar Seghir also contained three naves parallel to the qibla, a wall clearly marked by its mihrab niche and the minbar's chamber. The covered praying hall was preceded by a courtyard with at least one portico on the southwest side. ${ }^{25}$ Christian adaptation transformed the portico into chapels with painted altars and reorganized the northeast part of the former mosque, adjacent to the main public square, as a re-oriented nave facing a newly built five-sided head chapel. The long rectangular space turned the attention away from the original mihrab and the Portuguese back and front sections of the building now emphasized Christian symbols-a new altar towards the southeast and a bell tower instead of the minaret next to the main entrance of this newly adapted church.

Only more archaeological research will fully clarify further aspects of the architectural transformation. Nevertheless, building adaptation did not just relate to religious structures. It involved many other constructions among which the captain's headquarters played as much of a symbolic role as churches or cathedrals. Also in Ksar Seghir one can still note the metamorphosis that occurred

25 Charles L. Redman and James L. Boone, "Qsar es-Seghir (Alcácer Ceguer): a 15th and 16th Century Portuguese Colony in North Africa," Studia 41-42 (September 1979): 20-21. 
in the former Islamic sea gate, Bab al Bahar. In 1460 , it was transformed into the captain's house since there was a lack of appropriately noble residences in the rest of the town. ${ }^{26}$ At first, a straightforward accommodation under the vaulted double-chambered gate was undertaken, and the defensive structure was reinforced by the erection of a round circular tower. A few decades later, this was followed by a larger program aimed at defining a walled perimeter encircling the former Islamic sea gate. ${ }^{27}$ Although it was mainly a defensive structure established around a central court which provided access to two layers of fire capacity and was connected to the sea by a long fortified bastion called couraça, the Portuguese castle provided a new image of the installed lord in former North African Muslim strongholds. This castle acted not only as a military back-up in case of enemy penetration in town, but also as a lavishly decorated building where grand windows allowed the captain to address the local population whenever public announcement were required.

Ksar Seghir is near two other cities which were captured by the Portuguese in 1471, Asilah and Tangier, where significant rhetorical architectural statements were also visible. In the latter, the Moorish kasbah was completely replaced by a new building on which a late-Gothic language can be read. The new château-type structure was closer to

26 "E por que naquella uilla nom auya casas em que se elle bem podesse aloiar. Todo o mês de Setembro entendeo em mandar fazer huuns paaços muy nobres com que afortellezou e afremosentou o castello da uilla," in Gomes Eanes de Zurara, Crónica do Conde D. Duarte de Meneses, ed. Larry King (Lisbon: Universidade Nova de Lisboa, 1978), 235. "It. Nos arcos mouriscos sobre que o dicto apousentamento esta fundado que estam na casa onde o dicto capitão ..." in Regimento das obras de Alcácer Ceguer, Évora, December 20, 1508, in Arquivo Nacional da Torre do Tombo (AN/TT), Corpo Cronológico, II, m. 19, n. 106.

27 "It primeiramente queremos que na dicta villa se faça hua barera que cerque as casas do apousamento do capitaom ...," in Regimento das obras de Alcácer Ceguer. a palatine acropolis than to a military facility, as observed in Braun's atlas (Figure 24.3). ${ }^{28}$ It was mostly blind at ground level, pierced by generous windows on the first floor and covered by tiled roofs punctuated by chimneys. Since this upper castle did not fulfill any defensive duties, serving rather as an emblematic representation of the Portuguese crown overseas, another castle was then needed in Tangier's lower city. Although more pragmatically located, to allow the effective control of the harbor and its activity, the late fifteenth-century castle boasted late-medieval architectural features such as a donjon crowned by machicoulis and watch-towers. It seems that architecture required a visual language that was portrayed in constructions seen from afar or from sea, even if outdated military.

A very similar prismatic tower still survives in Asilah. Built in the early years of the sixteenth century by master builder Diogo Boytac, ${ }^{29}$ this atavistic donjon did not have a specific use other than to declare Portuguese lordship over the town and its surroundings. In both Tangier and Asilah, the towers sent rhetorical messages of power and of Christian settlement in Africa, using military vocabulary, now devoid of its original function and made obsolete by the emergence of artillery, to claim political and religious rights over Maghribi lands. This is particularly evident in Asilah where the donjon is in clear contradiction with the coeval update program of building pre-modern bastions and walls. So, at a lower level, thicker walls, intercepted by pointed bastions, renewed the indispensable military capacity of the enclave that the donjon was not performing.

\footnotetext{
28 Braun et al., Civitates Orbis Terrarum, I, 57r-57v.

29 Archivo Histórico Portuguez (Lisbon: 1903-18), I, 365: "Mandámos ora tomar a Diego de Alvarenga, cavaleiro da nossa casa, de todo o dinheiro e cousas que recebeo e despendeo nas obras da nossa villa de arzila, os annos de 509 e 510, em pagamento dos soldos da gente que na dita villa serviu, ...; e 10:00o rs. de mestre Butaqua; ...".
} 


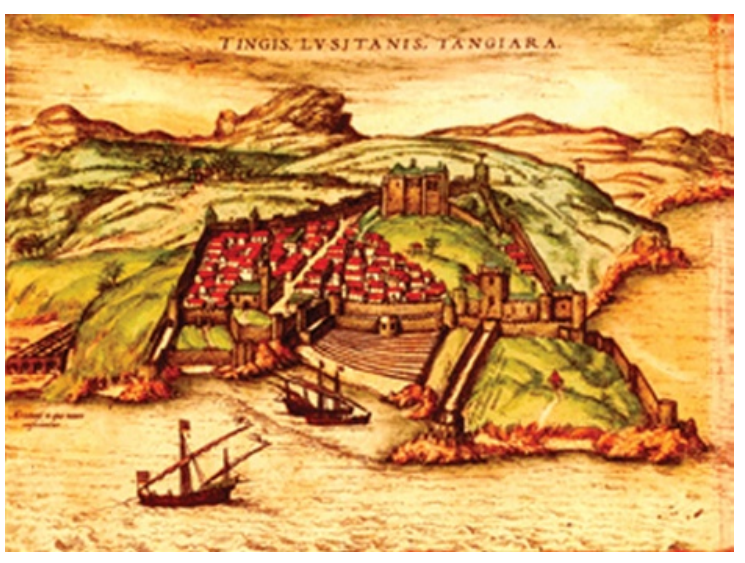

FIGURE 24.3 Tingis, Lusitanis, Tangiara

IN BRAUN ET AL., CIVITATES ORBIS TERRARUM, VOL. I, FOL. 56R

\section{3}

Urban Appropriation

Portuguese influence in former Muslim cities on the northwestern coast of Africa was not just limited to changes in their public buildings, but took the whole urban fabric into account in the establishment of new city concepts. As introduced in the beginning of this essay, frequently the captured walled-in area was too large for the scarce military means of the conqueror. Thus, new walls were introduced in order to cut short the preexisting urban limits and, by doing so, to optimize the Portuguese military disposition. Consequently, this technique led to a radical analysis of the appropriated cities, regularizing them geometrically, selecting an area of the former Muslim city which was closer to the sea or river mouth, and re-evaluating their internal disposition. These operations left a strong Portuguese footprint, still readable in Morocco's modern cities.

The results of the application of these techniques show a propensity for geometrically regular shapes where the construction of curtain walls established ninety-degree angles with the pre-existing defensive structures, excluded sprawling inland sections, and opened the urban space to the harbor. All decisions made by the Portuguese enhance the effect of straightening the former Islamic medina's curved limits. In the vicinity of the port, new buildings were built in order to respond to a developing market of exchanges between Europe and the Maghreb: customs, an exchequer, and sometimes even a mint. The examples of Ceuta, Tangier, or Safi reveal another distinctive factor, a double atalho, which is only present in the larger Portuguese possessions that earned the status of a city (cidade), because they housed a cathedral and were the headquarters of a whole diocese.

After the process of reduction, sectors of former Islamic cities were preserved within a tighter perimeter of walls. The new image of the urban space, pursued in an attempt to create a European identity, faced difficulties when encountering Muslim fabrics and households that were deeply rooted in the urban landscape. The overall built environment aspect which had resulted from the Christian short Byzantine and late-antiquity periods in areas closer to the Strait of Gibraltar, notably in cities such as Ceuta or Tangier, seems to have been completely altered during the centuries of Muslim presence. Not only earlier pagan temples, but more importantly paleo-Christian basilicas gradually disappeared, as did any remnants of grid planning, which were either abandoned or deeply reconfigured. Therefore, the non-Muslim built heritage was almost completely absent in the newly conquered cities. It was a situation the Portuguese felt the need to evaluate.

One can speak of a first degree of urban transformation in such cases as Ceuta, Ksar Seghir, and Tangier, on the Strait of Gibraltar shore, or Safi, further south, where very practical decisions were taken. Generally, the selection of morphological urban elements from the conquered city was the most evident and easy way of settlement. Therefore, from the earliest years the Portuguese tried to identify familiar signs in the street layout. For example, one of Islamic Ceuta's main thoroughfares, Zanqat Ibn Isa, was immediately assumed as the new main street - the Portuguese for rua Direita-because of its width and linearity. ${ }^{30}$ Traditionally in medieval Portuguese towns, rua

$30 \quad$ Leopoldo Torres Balbas, Ciudades hispano-musulmanas (Madrid: Ministerio de Asuntos Exteriores, 1985), 
Direita connected important town gates, usually the sea with the countryside, or streets with notable public buildings. Furthermore, it allowed space for public displays: the military parades or religious processions which were important symbols of European expansion beyond the Mediterranean.

Invariably, the main street would debouch in or be interrupted by a wider open space interpreted as a new public square. Portuguese central squares or yards were places of gathering, which housed the local market, or permitted public announcements by the governor or captain. They also articulated several secondary arteries. But such public spaces were rare in Muslim cities in the Maghreb. These presented a model where communal spaces were usually absent from the urban environment and remained mainly concentrated in public buildings such as mosques or baths (hammam). Moreover, even the few existing large open-air precincts for religious use, called musallà or saria, which were located just outside the walls or next to a cemetery,31 were automatically excluded following the atalho procedures. So, Ksar Seghir's 'terreiro' or Ceuta's 'aira' were aimed at establishing a regular geometric configuration that linked rua Direita with the castle, main church and connecting streets. As a consequence of this urban design process, a tendency in the urban fabric toward a grid plan was the result of decades of the slow Portuguese regularization of streets and establishment of new squares.

New values were demonstrated through a change in lifestyle that encouraged the opening of more windows toward the public space, reversing the intimacy and privacy issues that had been a strong feature of the former Muslim inhabitants' urban behavior. Morphological urban consequences were reflected through a continuous

I, 337; and Gomes Eanes de Zurara, Crónica da tomada de Ceuta, ed. Francisco Maria Esteves Pereira (Lisbon: Academia das Sciências, 1915), 214. Rua Direita literally means 'straight street' but its most accurate meaning is 'direct street,' though it was often winding and marked by hairpin bends.

Torres Balbas, Ciudades hispano-musulmanas, I, 219-20. rejection of the former fabric and its gradual correction vis-à-vis a regular plan that, nevertheless, was never fully established in the majority of Portuguese possessions. Resources were scarce and massive urban plans were usually out of the question in cities that witnessed frequent warfare.

However, a second degree of urban settlement occurred in Azemmour and Asilah where signs of regular planning are clearer. In the early decades of the sixteenth century there were opportunities to create new towns from scratch, taking advantage of completely or almost empty areas that were free from the constraints of existing buildings, as was usually the case in the conquered coastal cities analyzed previously. On the one hand, the Portuguese castle/town of Azemmour, which resulted from the process of downsizing of a larger Arab city, encountered adaptable landmarks only in the former kasbah and mosque. The rest of the European castled precinct was described as almost void or at least ruined, making it easier for the Portuguese to draw a new town. On the other hand, Asilah had reborn from the ashes of the destruction caused by an Arab assault in 1508 .

Occupied earlier in 1471, only by the turn of the century did King Manuel I feel the need to implement defensive measures and agreed to downsize the seized area. The Arab attack accelerated the process of building up an atalho, which preserved less than half of the former surface area, formed around a castle and a town (vila), with its axis on the rua Direita. Asilah's plan shows a discernable grid based on long quadrangular figures, concentrated between the town, sea, and castle gates, the areas most probably affected by the 1508 military incursion. Altogether there are seven rectangular-shaped units, with lengths consistently measuring $62-66 \mathrm{~m}$. Very similar measurements can be extracted from Azemmour's Portuguese layer of its urban form.

\section{$4 \quad$ New Foundations}

Both Azemmour and Asilah show a different side of Portuguese building propaganda in North 
Africa. Not only did mosques evolve into churches and Muslim castles into princely houses, but the urban context was also converted into identifiable aspects of a new town scheme that followed metropolitan modes of urbanization. If the foundational basis of these two cases is rather entangled in a dense process of military appropriation, there are other case studies that were settled over completely empty or scarcely inhabited territory, and Mazagão was the most successful of these. In fact, as the chronologically latest example, it can be considered the summit of accumulated building experience, and it shared its pattern of long rectangular-shaped built units with Asilah and Azemmour (Figure 24.4).

After the conquest of the neighboring town of Azemmour, the Portuguese established a castle in Mazagão the following year. Diogo and Francisco de Arruda, renowned Portuguese master builders, composed a quadrangular structure with curtain walls linking four cylindrical towers. ${ }^{32}$ In ${ }^{1541}$, Mazagão saw new investment with the building of a modern bastioned fortification and a walled town around the earlier castle on a grid plan. This royal initiative by King João III (1521-1557) was managed by a team of architects led by Benedetto da Ravenna and built by João de Castilho. ${ }^{33}$ For more than two centuries, the impregnable Mazagão remained in the hands of the Portuguese crown.

The locality of the first square castle, meanwhile transformed into central headquarters housing several storage halls, a hospital, a cistern, and other administrative buildings, seems to have worked as a catalyst for the projected town in 1541 . It also provides the metric base for the Mazagão's grid plan, since the regularity of the blocks derives from the subdivision of the square unit into half portions. This matrix can be more accurately

32 Letter from Francisco de Diogo de Arruda to Manuel I, Azemmour, Mars 31, 1514, in AN/TT, Corpo Cronológico, $1^{\text {a }}$ parte, m. 15 , n. 14 .

33
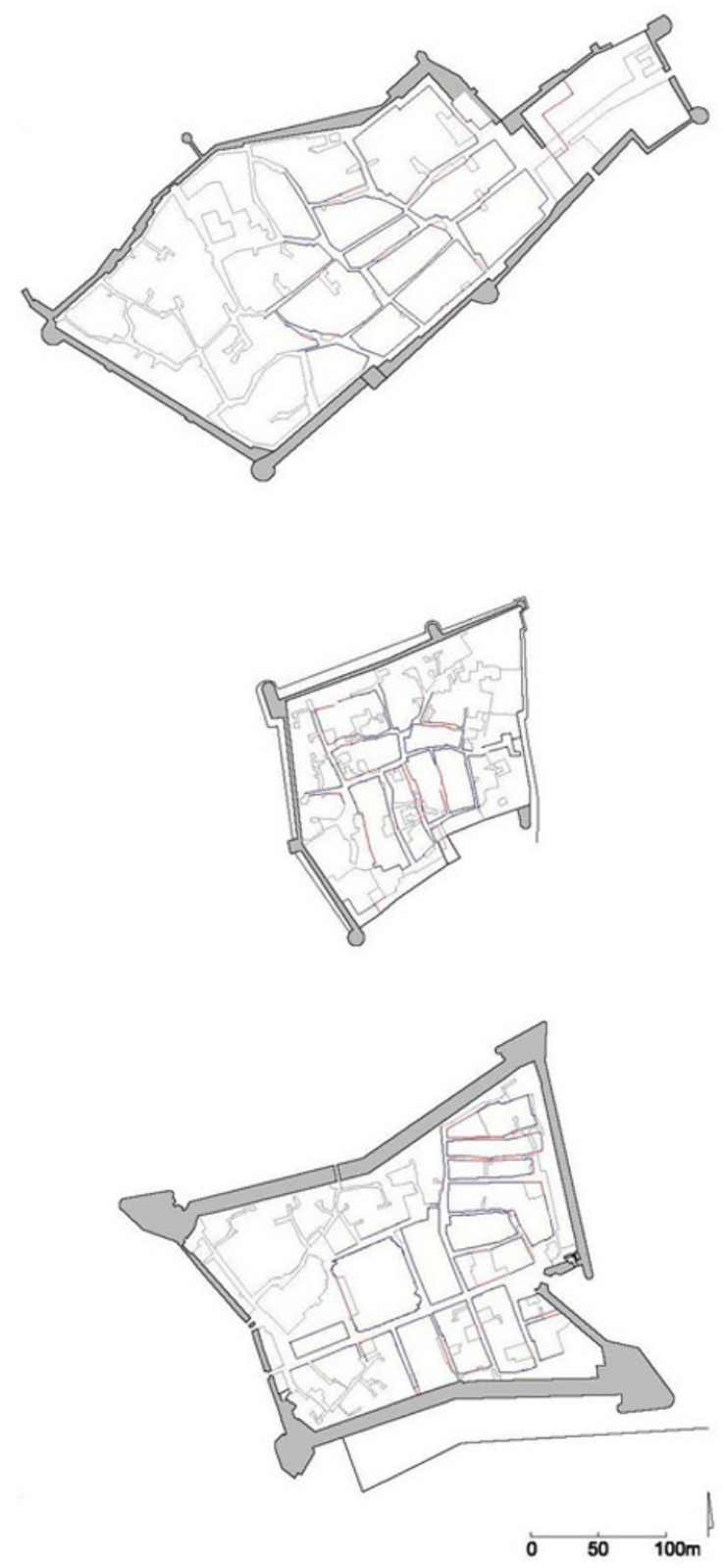

FIGURE 24.4 Comparative diagram of Asilah, Azemmour, and Mazagão's urban fabrics (from top to bottom)

(C) JORGE CORREIA

verified in southern and eastern areas of the town. Nonetheless, the project of Mazagão seems to have gone beyond a merely mathematical orientation for the city (Figure 24.5).

The 1514 castle, around which the whole plan was conceived, acted as the literal heart of a 
newly established Portuguese outpost. The corners of this quadrilateral structure launched diagonals that defined the position of the new fortified bastions, with the exception of $S$. Sebastião bastion. To the west, an open yard matches the same square surface of the original 1514 castle, bordered by the governor's palace, the town gate, and a broad street called Carreira. In fact, four other square figures can be enclosed within the fortified walls, drawing the shape of a Christian cross. Its base is right at the sea gate entrance and the main axis is followed by the widest street. The second cross axis intersects the first at the former castle, now a water, cereals, and ammunition provider for the town. Both transepts help to define northern and southern urban limits. Lastly, Mazagão's main church is located at the top of this virtual cross, which also allows the connection to the hinterland through the town square.

The plan is charged with a significant symbolic meaning intertwined with a rational spirit found in Cartesian geometries. The entire military precinct should also be understood as a sacred place for a Christian settler who expressed himself through façades or architectural structures as well as urbanism. Both secular and sacred dimensions seem to have traveled simultaneously in letters and orders sent by the crown for the construction of Mazagão. As early as 1514, King Manuel I of Portugal was sending furniture and ornaments for the small and primitive chapel that was all the first castle could accommodate, thus announcing from

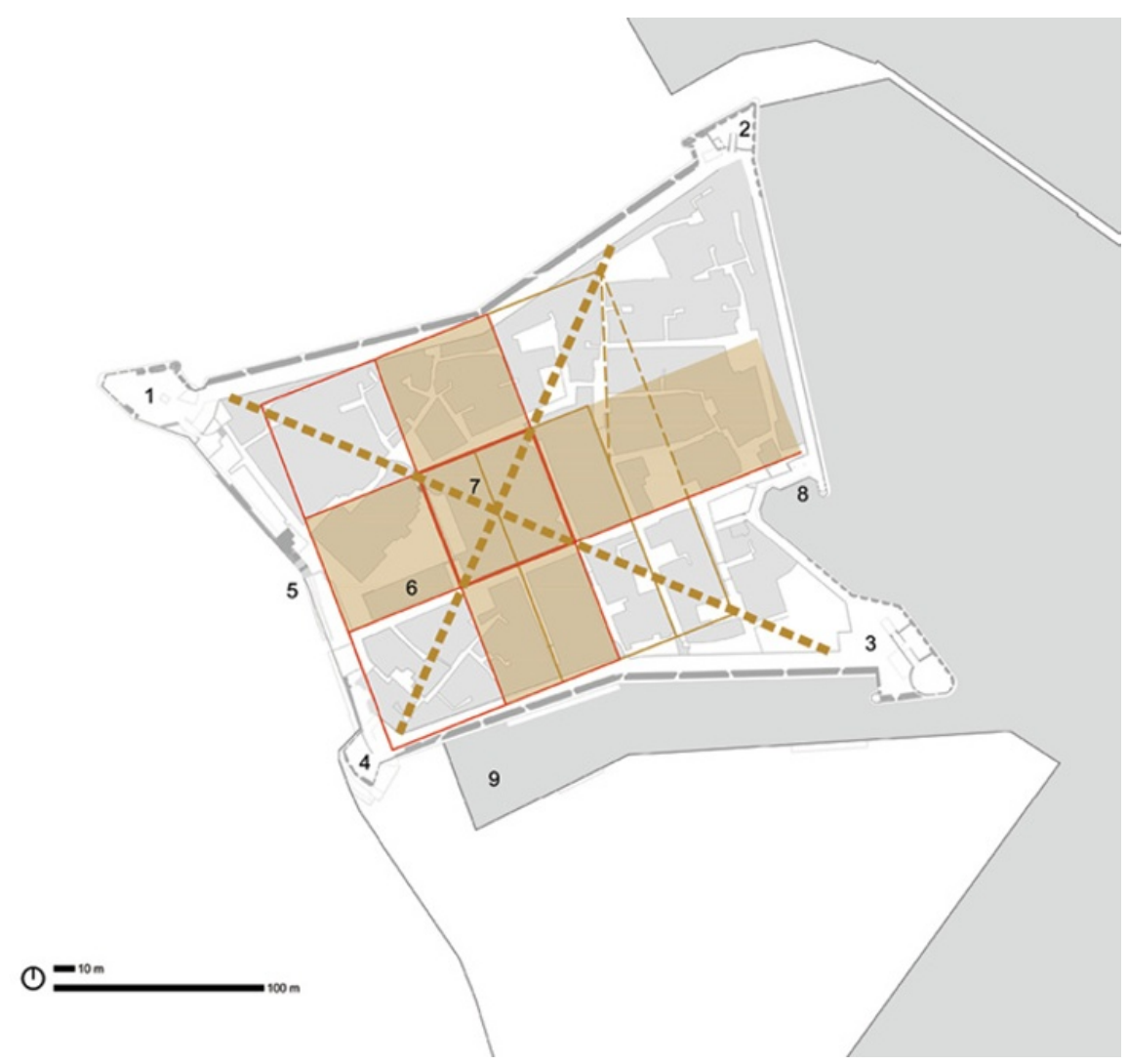

FIGURE 24.5 Plan of the Cité Portugaise, in El Jadida (former Mazagão): interpretive scheme.

1. Bastion of Santo António 2. Bastion of São Sebastião 3. Bastion of Anjo

4. Bastion of Santo Espírito 5. Town Gate 6. Church of Nossa Senhora da

Assunção 7. Former Manueline castle 8. Sea Gate 9. Moat

(C) JORGE CORREIA AND ANA LOPES 
the outset the importance of this religious activity and presence. ${ }^{34}$ Later, in 1547 , his successor and the patron of the modern foundation, corroborated the tone by asserting that the fortress would always be kept in a state of defense-not only its ramparts but also its church. ${ }^{35}$

Mazagão represents an evolution in terms of military architecture, although its plan is still a compromise with the urban tradition developed in the examples of occupation by conquest. Nevertheless, this stronghold acted as the firm rhetorical answer to the emerging Saadi dynasty (1554-1649) attacks. After the Portuguese withdrawal in 1769, Mazagão remained devoid of people for more than half a century because it was considered to be an 'unfaithful' land by the local Moroccan population. ${ }^{36}$

\section{Conclusion}

To sum up, new buildings and urban spaces established by the Portuguese on North African soil were as strong as a weapon. The message carried by architecture and urban display was as political as religious. The degree of intensity of such rhetorical discourse could range from a simple cross, framed in a former mihrab, to the conception of an entire town or a revised image of the city. From Ceuta to Safi, this was the main strategy that ended up conveying a new Christian stratum in the city's hypertext continuum.

Levels of propaganda ranged from symbolic statements, whenever a Christian consecration of a former mosque took place, to more explicit and visual apparatus. Flags waved on balconies and

\footnotetext{
34 Order by Manuel I, Lisbon, Agosto 8-23, 1514 in AN/TT, Corpo Cronológico, $1^{\text {a }}$ parte, m. 15, n. 117.

35 Letter from Luís de Loureiro to João III, Mazagão, Agosto, 27,1547 , in AN/TT, Corpo Cronológico, $1^{\circ}$ parte, m. 79 , n. 71.

36 For example, see Joseph Goulven, La Place de Mazagan sous la domination portugaise (1502-1769) (Paris: Émile Larose, 1917).
}

towers claimed ownership and religious rights to the new settler. Inside the walled contour, geometry played a central role, rationalizing block shapes and designing more linear street layouts. New buildings worked as architectural manifestos in their interaction with the previous urban ArabIslamic built environment, contributing to the creation of a new city image.

Controlled surface dimension and geometrical reshaping of conquered cities, linearity and perspective alignments of streets, as well as the redesign of public spaces were actions that the Portuguese empirically used, applying a caseby-case assessment. Sometimes they were clearly related to the establishment of late-medieval bastides or new towns, 'exported' to North Africa in the pursuit of a late Christian Reconquest beyond the Strait of Gibraltar. This was the case of the majority of the conquests, and especially Azemmour and Asilah.

Although, traditional historiography has stressed the mercantile advantages and military achievements of Northern African campaigns for the Portuguese Crown, the Moroccan project was clearly imbued with an evangelical goal of withdrawing Islam from the region. Thus, the probable religious significance of the urban layout, besides the military conquest itself, and the overruling of Muslim spaces and objects by Christian ones, worked as strong visual statements. If any doubts remain after the analysis of the seized-and-transformed nuclei the Portuguese had conquered along the seashore, the founding of Mazagão's underlines how architecture and urban design have played decisive roles in the settlement of sacred precincts by the Portuguese in North Africa. Therefore, building cities and/or (re)building architectural structures was a form of spatial scenography performance for staging religious messages and fostering social identities.

The ultimate desire of the Christian Reconquest was to wrest this territory from the hands of Muslim rulers. The urban space was not to be shared by different ethnicities and, therefore, 'new' cities and their buildings must be understood as a 
European cultural product. In a climate of almost permanent hostility and conflict, where the walls of the city are essentially the political boundary of the Portuguese presence in the Maghreb, former aspects of the Islamic built environment were transformed and converted to create an order echoing a new identity. Even though military conditions changed by the mid-150os, interrupting the major political designium of conquering all Morocco, the Portuguese appropriation and adaptation processes show an essay of redeeming the failed conversion of the country through new messages in building ornaments or urban displays. 